\title{
PROJECT BASED LEARNING TO ENHANCE CREATIVE THINKING SKILLS OF THE NON-SCIENCE STUDENTS
}

\author{
$\mathrm{Y} \mathrm{Yamin}^{a, b, *)}$, A Permanasari ${ }^{a)}$, S Redjeki ${ }^{a)}, \mathrm{W}$ Sopandi ${ }^{a)}$ \\ ${ }^{a)}$ Universitas Pendidikan Indonesia, Bandung, Indonesia \\ ${ }^{b)}$ Universitas Pakuan, Bogor, Indonesia \\ ${ }^{*}$ Corresponding Author: yamin.adisaputra@yahoo.com
}

\begin{abstract}
This study was aimed to describe students' creative thinking skills in integrated science learning on the theme of water pollution using project-based learning. The method used in this study was a descriptive method. The population and sample in this study were non-science students at a university in Bogor. The instruments used in this study were tests of creative thinking skills, peer assessment and product creativity assessment rubrics. The results showed that the average test score of students' creative thinking skills was $89 \%$ (very good category). The achievement of peer assessment indicators is $87 \%$, while the achievement of product creativity indicators is $88 \%$. Thus, it can be concluded that project-based integrated science learning can be used to improve the creative thinking skills of non-science students.
\end{abstract}

Keywords: project based learning; creative thinking; non-science

\section{INTRODUCTION}

Water pollution is a deviation of the properties of water from its normal state, not from its purity. The characteristics of polluted water depend on the types of water and its pollutants or components that cause pollution. The properties of water that are commonly tested and used to determine the level of water pollution are $\mathrm{pH}$ values, BOD/COD values, pollution of pathogenic microorganisms, oil content, heavy metal content, and radioactive material content [1].

Water pollution is one of the natural phenomena that we often encounter in our daily life, and this phenomenon will cause many negative impacts on human life. The negative impacts among the people include the difficulty to get clean water, the potentila of various diseases including skin diseases, the disruption of the balance of the water ecosystem, and there are still many other negative impacts caused by water pollution. Water pollution may be caused by the disposal of garbage into rivers, industrial waste and household waste and excessive use of chemicals for agricultural activities in rice fields [2]. Through this water pollution phenomenon we can develop students' abilities to find solutions to problems faced in everyday life. This capability can be developed through meaningful science learning.

Science is a collection of systematically arranged knowledge, and it is generally used in natural phenomena. The further development of science is not only marked by the existence of a collection of facts, but also the emergence of scientific methods that are created through a series of scientific work (working scientifically), scientific values and attitudes. Science learning is closely related to the understanding of concepts and abilities of thinking [3].
With meaningful science learning, it is expected to improve the mindset of the students. One of the mindset developed in science learning is creative thinking skills. Through this studu, it is expected that science learning will become more meaningful because it stimulates students to find new ideas in solving problems [4].

Creative thinking skills are thinking skills that reflect flexibility, fluency and originality in thinking and the ability to develop ideas and to apply them in solving problems[5]. Creative students, in the learning process will explore things that have been actively studied. Creative thinking is issuing and expressing ideas that are new, fresh and useful for solving problems [6].

Developing creative thinking skills allows students to gain more understanding of the topic, to be more critical about evidence, to think flexibly and to make judgments and decisions that lead to conclusions. That kind of thinking skills is needed both at school and in the wider world. Students need to develop the thinking strategies that can be used when they face new situations [7].

In the process of learning science, students are not only required to develop their cognitive potential but are also expected to be able to develop their skills holistically. Therefore, by implementing science learning in an integrated manner it is hoped that it will facilitate students in applying science concepts in everyday life. This learning can provide direct experience so students can find themselves a concept that is meaningful and authentic. There are 10 types of cohesiveness, namely fragmented, connected, nested, networked, shared, threaded, integrated, webbeb, sequenced and immersed [8].

Integrated science learning begins to be applied in several countries. Several studies have been conducted to see the effectiveness of the application of integrated science 
learning $[9,10,11,12]$. In the application of integrated science learning it needs to be supported by professional teachers who are able to apply integrated science learning in the classroom well [13]. In addition, it needs to be supported by appropriate learning activities that are able to stimulate students to be more active in the learning process. One model that can be applied is project-based learning.

Project Based Learning is one of the learning models that can stimulate students to be actively involved in the learning process. Project-based learning has enormous potential to make learning experiences more interesting and meaningful for students [14]. The model has been shown to have a positive impact on students such as improving student achievement, mastery of students' concepts, attitudes of students towards science, activeness of students following learning and learner learning abilities $[15,16,17,18,19,20$ $21,22,23,24]$.

Research on project-based learning is increasingly developing, including project-based learning in integrated science. The results are still not satisfyinh because projectbased integrated science learning is still difficult to implement in the classroom because of several obstacles including time, curriculum, availability of tools/materials and teacher's understanding of project-based learning [25].

In integrated science learning, one theme is needed which aims to facilitate the teacher in organizing and integrating subject matter content. The theme of water pollution was chosen in this study. This theme will be reviewed from the disciplines of Physics, Chemistry and Biology. The subject of this water pollution theme includes changes in substances, the role of heat in substance form changes, water cycle, mixture, technology/methods of mixture separation, environmental pollution and the role of humans in environmental management. Through projectbased integrated science learning on the theme of water pollution, it is expected to improve students' creative thinking skills.

\section{RESEARCH METHODS}

The method used in this study was descriptive method, research which was directed at exploring data from actual conditions [26]. The data in this case were creative thinking skills, with creativity as a process (peer assessment) and product creativity produced by students in the integrated science learning on the theme of water pollution. The study was conducted at one of the universities in the city of Bogor with a sample of the 54 freshmen of the non-science students. The instruments used in this study were tests of creative thinking skills, peer assessment and product creativity assessment rubrics.

\section{RESULTS AND DISCUSSION}

Meaningful science learning was expected to improve students' creative thinking skills. Students were directed to find solutions to problems faced in everyday life. The theme raised in this study was water pollution. With integrated science learning on the theme of water pollution, students were directed to think creatively to find solutions in an effort to overcome water pollution. Science learning used in this research was integrated science learning. The integrated science learning design on the theme of water pollution carried out in this study can be seen in Figure 1.

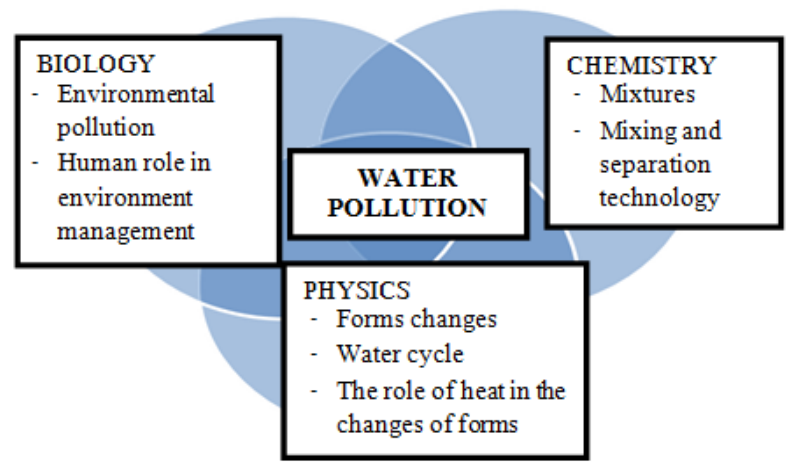

Figure 1. Design of integration science on the theme of water pollution

In Figure 1, it can be seen that the material taught on the theme of water pollution includes changes in matter, heat effects on substance form changes, water cycles, mixture separation, environmental pollution and the role of human in environmental management.

Through project-based learning on the theme of water pollution, it was expected that the students could improve thier creative thinking skills. Creative thinking skills were captured through tests of creative thinking skills, creativity as a process (peer assessment) and creativity of the products produced.

\section{A. Implementation of Project Based Learning}

To assess the implementation of Project Based Learning, the observer used an observation sheet. The results of the recapitulation of the observation sheet can be seen in Table 1.

Table 1 shows that Project Based Learning on the theme of water pollution run well, according to the stages of project-based learning. There were 6 stages of project-based learning, namely the start with the essential question, the design plan for the project, the schedule arrangement, the monitoring toward the students and the progress of the project, the outcome assessment, and the evaluation of the experience [27].

\section{B. Test of Creative Thinking Skills}

The test of creative thinking skills in this study used indicators of creative thinking skills proposed by Torance, including fluency, flexibility, originality and elaboration [28], which were then described in Munandar into several sub-aspects [29]. Achieving the test of creative thinking skills based on each sub-aspect can be seen in Table 2 . 
Table 1. Recapitulation of Project Based Learning implementation

\begin{tabular}{|c|c|}
\hline Observed Items & Observer's Evaluation Summary \\
\hline $\begin{array}{l}\text { Step 1:Start with the } \\
\text { essential euestion }\end{array}$ & $\begin{array}{l}\text { In the early stages of Project Based } \\
\text { Learning, the students actively answered } \\
\text { questions. }\end{array}$ \\
\hline $\begin{array}{l}\text { Step 2: Design a plan for the } \\
\text { project }\end{array}$ & $\begin{array}{l}\text { In designing project planning, each } \\
\text { group member gave each other ideas, but } \\
\text { students appeared to be a little confused } \\
\text { in designing project planning. }\end{array}$ \\
\hline Step 3: Create a schedule & $\begin{array}{l}\text { At the stage of arranging schedules, } \\
\text { students appeared active and shared their } \\
\text { own ideas well. The project was } \\
\text { completed on time according to a } \\
\text { predetermined plan. }\end{array}$ \\
\hline $\begin{array}{l}\text { Step 4: Monitor the students } \\
\text { and the progress of the } \\
\text { project }\end{array}$ & $\begin{array}{l}\text { Monitoring the students and the progress } \\
\text { of the project was not only carried out } \\
\text { during learning but also carried out } \\
\text { through media communication tools } \\
\text { such as mobile phones. }\end{array}$ \\
\hline Step 5: Assess the outcome & $\begin{array}{l}\text { The results testing stage was done } \\
\text { through product presentations and tests } \\
\text { in front of other students. All students } \\
\text { looked enthusiastic. }\end{array}$ \\
\hline $\begin{array}{l}\text { Step 6: Evaluate the } \\
\text { experience }\end{array}$ & $\begin{array}{l}\text { The stage of evaluating the experience } \\
\text { was done by asking questions and } \\
\text { sharing experiences during the project } \\
\text { creation process. }\end{array}$ \\
\hline
\end{tabular}

Table 2. The achievment of tests of creative thinking in each aspect

\begin{tabular}{lc}
\hline \multicolumn{1}{c}{ Sub-aspects of creative indicators } & Indicator Achievement \\
\hline Ability to think smoothly & $87 \%$ \\
Ability to think flexibly & $89 \%$ \\
Ability to think originally & $92 \%$ \\
\hline Ability to specify & $84 \%$ \\
\hline Ability to assess (sensitivity) & $85 \%$ \\
\hline Curiosity & $91 \%$ \\
\hline Imaginative nature & $91 \%$ \\
\hline Responsibility for pluralism & $90 \%$ \\
\hline Courage to take risks & $89 \%$ \\
\hline Appreciation & $96 \%$ \\
\hline \multicolumn{1}{c}{ Average } & $\mathbf{8 9 \%}$ \\
\hline
\end{tabular}

Table 2 shows that of all indicators of creative thinking, if interpreted into the ability category according to Arikunto [30], are classified as excellent category. In other words, project-based integrated science learning can help stimulate students' creative skills. This is in accordance with Rais's opinion [31] which states that the use of Project Based Learning is able to encourage an increase in student academic results. This learning model is able to provide an environment for students to develop a skill in this case creative thinking skills.

\section{Peer Assessment}

To find out the creativity process carried out by students during the learning process and product making, peer assessment was used. Peer assessment contains data checklist Yes or No for each aspect indicator of creative thinking skills. Each student provided an assessment of himself and his friends in one group. Furthermore, the overall calculation is done using a percentage $(\%)$ of each indicator. The results of student process creativity assessment can be seen in Table 3.

Table 3. Recapitulation of peer assessment

\begin{tabular}{lc}
\hline \multicolumn{1}{c}{ Sub-aspects of creative indicators } & Indicator Achievement \\
\hline Ability to think smoothly & $89 \%$ \\
Ability to think flexibly & $85 \%$ \\
Ability to think originally & $88 \%$ \\
\hline Ability to specify & $91 \%$ \\
\hline Ability to assess (sensitivity) & $81 \%$ \\
\hline Curiosity & $86 \%$ \\
\hline Imaginative nature & $76 \%$ \\
\hline Responsibility for pluralism & $83 \%$ \\
\hline Courage to take risks & $92 \%$ \\
\hline Appreciation (toward ideas and opinion) & $95 \%$ \\
\hline Appreciation (toward the products) & $97 \%$ \\
\hline \multicolumn{2}{c}{ Rata-rata } \\
\hline
\end{tabular}

Table 3 shows that the achievement of students' process creativity is $87 \%$, if interpreted into the ability category it is classified as very good category. The results of the achievement of this peer assessment, when compared to the results of the creative thinking test, are not significantly different. Achievement of peer assessment is $87 \%$, while the creative thinking test is $89 \%$. If the value of the $\mathrm{N}$-Gain peer assessment is calculated with the creative thinking test, the result is 15.38. If it is Interpreted based on the $\mathrm{N}$-Gain value category), the N-Gain is classified as the low category. This means that the test of creative thinking with peer assessment (process creativity) of the experimental class students does not differ significantly.

\section{Product Creativity}

Products designed by students were the solution to the problems faced, which was water pollution. The products in the form of water filters. Students were divided into 4 groups. Each group was given the freedom to determine the materials and methods used to make water filters according to their creativity. After that they explained and tested the products they had made.

The assessment of the creativity of the products produced by students uses the product creativity assessment rubric (scales 1-3). Furthermore, the overall calculation is done using a percentage $(\%)$ of each indicator. The results of the achievement of product creativity assessment can be seen in Table 4.

Table 4 shows that the achievement of product creativity produced by students is $88 \%$, if interpreted into the ability category, it is included into very good category. This means the products produced by students included creative products. This is in accordance with what was conveyed by Eragamreddy [32], that creativity is the ability to produce/create something new, or develop from something that already exists.

Therefore, in this study it was found that through project-based integrated science learning on the theme of water pollution the students can improve creative thinking skills, process creativity (peer assessment) and product creativity. 
Table 4. Recapitulation of product creativity achievment

\begin{tabular}{lc}
\hline \multicolumn{1}{c}{ Indikator Produk Kreatif } & \multicolumn{1}{c}{$\begin{array}{c}\text { Indicator } \\
\text { Achievement }\end{array}$} \\
\hline $\begin{array}{l}\text { New products } \\
\text { New procedures }\end{array}$ & $67 \%$ \\
$\begin{array}{l}\text { Products resulted from } \\
\text { individual/group interactions } \\
\text { with their environment }\end{array}$ & $67 \%$ \\
\hline Originality & $93 \%$ \\
\hline Significance & $100 \%$ \\
\hline $\begin{array}{l}\text { The accuracy of the application } \\
\text { of the science concept in } \\
\text { making projects }\end{array}$ & $87 \%$ \\
\hline $\begin{array}{l}\text { Relevancy of application of } \\
\text { science concept in project } \\
\text { creation }\end{array}$ & $93 \%$ \\
\hline $\begin{array}{l}\text { Suitability of products made } \\
\text { with learning objectives } \\
\text { (achievement of basic } \\
\text { competencies) }\end{array}$ & $93 \%$ \\
\hline \multicolumn{1}{c}{ Average } & $100 \%$ \\
\hline
\end{tabular}

Through project-based learning, students not only identify problems and find solutions to problems faced, but students are also required to combine knowledge and creative thinking skills to produce products that can be a solution to the problems they face. With project-based integrated science learning, students are expected to be facilitated to develop themselves both academically and practically in their respective environments to find solutions to problems faced in everyday life.

\section{CONCLUSION}

Based on the analysis of the results of the study, it can concluded that meaningful science learning will help students develop creative thinking skills. Project-based integrated science learning on the theme of water pollution can improve students' creative thinking skills by $89 \%$ (very good category). The achievement of peer assessment indicators is $87 \%$, while the achievement of product creativity indicators is $88 \%$. Thus, project-based science learning can be an alternative to improve students' creative thinking skills of the non-science students.

\section{Acknowledgments}

I would like to thank all the stake holders of Pakuan University who have helped me both materially and morally.

\section{REFERENCES}

[1] Fardiaz S. 1992. Polusi Air dan Udara (Yogyakarta: Kanisius)

[2] Herlambar A. 2006. Pencemaran air dan strategi penanggulanganya Jurnal Alam dan Lingkungan 1 (2) $16-29$
[3] Kemendiknas. 2013. Materi Pelatihan Guru Implementasi Kurikulum $2013 \quad$ (Jakarta: Kemendiknas)

[4] Kemendikbud. 2013. Kompetensi Mata Pelajaran Ilmu Pengetahuan Alam Sekolah Menengah Pertrama (SMP)/Madrasah Tsanawiyah (MTs) (Jakarta: Kemendikbud)

[5] Munandar U. 2005. Mengembangkan Bakat dan Kreativitas Anak (Petunjuk Orang Tua). (Jakarta: Rajawali)

[6] Alblecht K. 1987. Daya Pikir (Semarang: Dahara Pize)

[7] James M. 2009. Thinking Skills and Assessment for Learning Development Programme (Bristol: Clifton College)

[8] Fogarty R. 1991. How to Integrate the Curricula (Palatine: IRI Skylight Publishing)

[9] Oludipe and Idowu D. 2011. Developing nigerian integrated science curriculum Journal of Soil Science and Environmental Management 2 (8) 134-145

[10] Samuel D. 2011. Science teachers' and students' perceived difficult topics in the integrated science curriculum of lower secondary schools in barbados World Journal of Education

[11] Ameyaw. 2011. Environmental pedagogies that promote students understanding of integrated science (biology aspect) Journal of Education

[12] Edokpayi J N and Suleiman M A. 2011. Students integrated science achievement as predicator of later achievement in chemistry: a case study among selected secondary schools in Zaria Metropolis Scholars Research Library

[13] Hafizan E, Halim L and Meerah S. 2012. Perception, conceptual knowledge and competency level of integrated science process skill towards planning a professional enhancement programme Sains Malaysiana 41 (7) 921-930

[14] Silberman M. 2005. Active Learning (Yogyakarta: Data Media)

[15] Yenice. 2011. The Impact of Project-Based Learning Approach in Science Education on Pre-Service Teachers' Attitudes for Science and Project Journal of Education

[16] Hemisoglu H. 2011. The Effect of Project Based Learning Approach in Social Sciences Class on the Student Success and Memorability Eurasia Journal of Mathematics, Science \& Technology Education, 7(3), 149-160

[17] Baran M and Maskan A. 2011. The effect of Projectbased Learning on Pre-Service Physics Teachers' Electrostatic Achievements Cypriot Journal of Educational Sciences

[18] Altunyalin S, Turgut U and Buyukkasap E. 2011. The Effect of Project Based Learning on Science Undergraduates' Learning of Electricity, Attitude towards Physics and Scientific Process Skills International Online Journal of Educational Science, 1(1), 81-105 
[19] Guo and Yang. 2012. Project-Based Learning: an Effective Approach to Link Teacher Professional Development and students Learning Journal of Educational Technology Development and Exchange, 5(2), 41-56

[20] Movahedzadeh F, Patwell R, Rieker J E and Gonzales T. 2011. Project-Based Learning to Promote Effective Learning in Biotechnology Courses Hindawi Publishing Corporation Education Research International

[21] Bagheri M, Ali W Z W, Abdullah M C and Daud S M. 2013. Effects of Project-based Learning Strategy on Self-directed Learning Skills of Educational Technology Students Contemporary Educational Technologi

[22] Cakici Y and Turkmen N. 2013. An Investigation of the Effect of Project-Based Learning Approach on Children's Achievement and Attitude in Science The Online Journal of Science and Technology Volume 3, Issue 2

[23] Ozer D Z and Ozkan M. 2013. The Effect of Project Based Learning Method on Science Process Skills of Prospective Teachers of Science Education in Biology Lessons. International Online Journal of Educational Sciences, 5 (3), 111-645

[24] Pitiporntapin S and Kuhapensang O. 2015. Using Project-based Teaching for Developing Thai PreService Science Teachers' Attitude towards Science International Journal of Science Educators and Teachers

[25] Kubiatko M and Vaculova I. 2011. Project-Based Learning: Characteristic and The Experiences With Application in The Science Subjects Journal Energy Education Science and Technology Part B: Social and Educational Studies. Volume (issue) 3(1): 65-74

[26] Sugiyono. 2011. Metode Penelitian Pendidikan (Bandung: Alfabet)

[27] Thomas J W 1999 Project Based Learning: A Handbook of Middle and High School Teacher (Novato CA: The Buck Intitute For Education)

[28] Torrance E P. 1998. The Nature of Creativity as Mainfest in its Testing (New York: Cambirdge University Perss)

[29] Munandar U. 2012. Pengembangan Kreativitas Anak Berbakat (Jakarta: Rineka Cipta)

[30] Arikunto S. 2003. Dasar-dasar Evaluasi Pendidikan (Jakarta: Bumi Aksara)

[31] Rais. 2010. Pengembangan Model Project Based Learning: Suatu Upaya Meningkatkan Kecakapan Akademik Mahasiswa Jurusan Teknik Mesin UNM (Laporan Penelitian Tahun II DP2M DIKTI-LEMLIT UNM)

[32] Eragamreddy, N. 2013. Teaching Creative Thinking Skills. International Journal of English Language \& Translation Studies, 1 (2) 